\title{
An environmental management industrial solution for the treatment and reuse of mussel wastewaters
}

\author{
M.A. Prieto a,*, I. Prieto ${ }^{\text {d }}$, J.A. Vázquez ${ }^{c}$, Isabel C.F.R. Ferreira ${ }^{\text {b }}$ \\ a Nutrition and Bromatology Group, Faculty of Food Science and Technology, University of Vigo, Ourense Campus, E32004 Ourense, Spain \\ b Mountain Research Centre (CIMO), ESA, Polytechnic Institute of Bragança, Campus de Santa Apolónia, 1172, 5301-855 Bragança, Portugal \\ c Grupo de Reciclado y Valorización de Materiales Residuales (REVAL), Instituto de Investigacións Mariñas (IIM-CSIC), Vigo 36208, Spain \\ ${ }^{\mathrm{d}}$ Faculty of Education and Sport, University of Vigo, Pontevedra, Spain
}

\section{H I G H L I G H T S}

- Mussel processing wastewaters (MPW) have been continuously dumped into the sea.

- MPW is causing the progressive deterioration of marine ecosystems in the NW of Spain.

- A biotechnological process to transform MPW into profitable bioproducts

- A sustainable process to integrate the mussel industry into the ecosystem

\section{A R T I C L E I N F O}

\section{Article history:}

Received 13 May 2015

Received in revised form 7 July 2015

Accepted 8 July 2015

Available online 22 August 2015

Editor: D. Barcelo

\section{Keywords:}

Industrial waste

Optimization

Sustainable industrial process

Mussel processing wastewaters

Bioseparation process

Isolation and purification
GRA P H I C A L A B S T R A C T

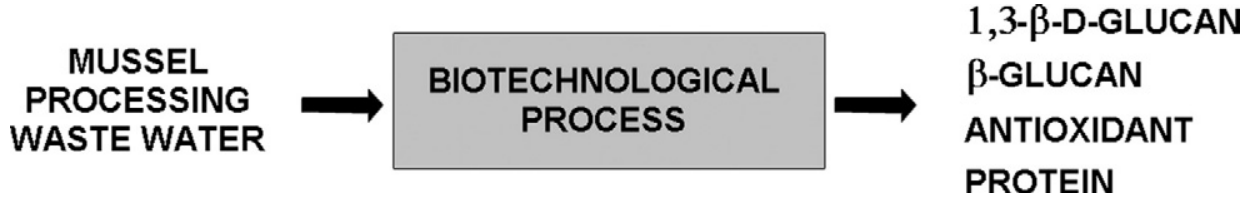

\begin{abstract}
A B S T R A C T
In the North-West of Spain, the annual production of mussel is $2 \times 10^{6} \mathrm{t}$ ( $35 \%$ of the world). The industrial thermal treatment of mussels generates between 300 and $400 \mathrm{~L} / \mathrm{t}$ wastewaters that are continuously disposed into the sea without previous treatment and or further reuse. These effluents, relatively rich in organic matter ( $7 \mathrm{~g}$ glycogen/L and $25 \mathrm{~g} \mathrm{COD} / \mathrm{L}$ ), contribute to the progressive deterioration of the marine ecosystem. We wish to suggest a biotechnological process, based on a laboratory optimization and industrial pre-scale trials, to transform these industrial effluents into a growth culture medium to produce microbial biomass. Furthermore, this biomass is isolated and treated by different optimized separation and purification processes to produce several bioproducts: 1) single cell protein; 2) cell wall material with a high content in glucans and glycoproteins 3 ) fractions of 1,3- $\beta$-glucans and mannoproteins from yeast cell walls hydrolysis; and 4 ) a potential antioxidant extract. Finally, the authors propose a scaled process for its industrial application. In consequence, we believe that this work provides an environmentally friendly, eco-designed and profitable solution that allows integrating the mussel industry into the ecosystem in a sustainable way.
\end{abstract}

C 2015 Elsevier B.V. All rights reserved.

\section{Introduction}

Since many years, the Galician scientific community has searched for a process to treat the effluents derived from the mussel processing industry that are being released to the estuary coastal waters at the NW of Spain $\left(\sim 100,000 \mathrm{~m}^{3} /\right.$ year $)$. Previous authors have suggested

\footnotetext{
* Corresponding author. Tel.: + 34654694616.

E-mail address: michaelumangelum@gmail.com (M.A. Prieto).
}

(González et al., 1987, 1992; Murado et al., 1993a,b) to transform the mussel processing wastewaters (MPW) into a suitable growth medium able to provide the carbon source for microbial fermentation showing clearly the viability of this approach. Also, this residual effluent has been successfully used for several bioproductions including citric acid, gibberellins, amylases, pediocin, glucose oxidase, hyaluronic acid, among others (Murado et al., 1997; Omil et al., 1996; Pastrana et al., 1995; Pintado et al., 1993; Ramasamy and Abbasi, 2000; Slater et al., 2009; Vázquez et al., 2013), encouraging its industrial application. Despite of the considerable environmental effects of MPW on the 
marine ecosystem, the seasonal uncertainty (Omil et al., 1996) and the low profitability of the by-products obtained, made a treatment, which is able to reduce the environmental impact of these continuous effluents, difficult at industrial level (Prieto et al., 2011).

Among the diverse number of microbial bioproductions, one alternative for the MPW, not yet examined, is to optimize the production of glucans from yeasts (Suphantharika, 1997). Glucans and glycoproteins are a diverse group of glycoconjugates, mainly made of carbohydrates with significant differences in their molecular mass, solubility, viscosity, and three-dimensional configuration. In vegetables, these compounds are associated with cellulosic cover structures, and in bacteria, yeast and fungi are components of the cell walls. In general, these compounds have several beneficial properties and many useful applications. The differences between soluble and insoluble $\beta$-glucans, as well as the differences between the types of links and their spatial structure are significant in regards to solubility, application, mode of action, and overall biological activity (Janusz et al., 1989; Kulicke et al., 1997). Mannoproteins, 1,3-3-D-glucans and insoluble fiber fractions showed beneficial effects on human health (Diez et al., 2010; Kim and Yun, 2006), such as immunostimulatory, antitumoral and anti-inflammatory properties (Bagni et al., 2005; Bohn and BeMiller, 1995; Marques et al., 2006). Authors have pointed out that glucans and glycoproteins have some ability to capture hydrophilic and lipophilic radicals (Altan et al., 2009; Jaehrig and Rohn, 2007; Jaehrig et al., 2008; Martínez-Tomé et al., 2004) and, therefore, they have been proposed as food additive with antioxidant features. Apart from of all these potential applications, the animal feed and veterinary industries are the sectors in which glucans applications are more extensively applied. Furthermore, a broad spectrum of living organisms (earthworms, shrimp, fish, pigs, etc.) have shown health benefits when they were fed with diets formulated with glucans and glyoproteins as ingredients (Beschin, 1998; Buddle et al., 1988; Skjermo et al., 2006; Suphantharika and Khunrae, 2003). In addition, glucans have demonstrated to be active compounds, increasing the natural resistance mechanisms to microbial pathogens (Figueras et al., 1998; Santarem et al., 1997), which has a direct application in the aquaculture field, substituting the typical misuse of antibiotics which is applied to reduce the high mortalities of fish larvae (Rodríguez et al., 2009).

The objectives of the present study were: 1 ) to select an appropriate microbial species for the biotechnological transformation of industrial MPW effluents into single cell protein (SCP); 2) to optimize the laboratory extraction of cell wall (CW), in order to obtain high value products for diverse applications; 3 ) to analyze the main composition of the glucans and glycoproteins products obtained and to quantify the corresponding yields; 4 ) to determine the potential antioxidant capacity in vitro of these products derived from biomass cell walls; and 5) to design a recycling process for MPW effluents in order to minimize the environmental impact by a profitable and cleaner technology and to integrate the mussel industry into the ecosystem in a sustainable way.

\section{Material and methods}

\subsection{Microbial methods}

\subsubsection{Strains}

The microbial species tested (all of them GRAS: Generally Recognized As Safe) were: a) the yeasts Saccharomyces cerevisiae (CBS 1907; abbreviation as Sc), Rhodotorula rubra (CECT 12891; Rr) and Saccharomyces fibuligera (other non-used synonyms: Endomyces fibuligera, Saccharomycopsis fibuligera CBS 2521; Sf); and b) the fungus Aspergillus niger (CBS 513.88; An) and Aspergillus oryzae (CBS 102.07; Ao). The inclusion of the first two yeasts obeyed only for comparative purposes in a conventional medium, since they are not amylolytic species and cannot metabolize the glycogen present in the MPW.

\subsubsection{Culture media}

2.1.2.1. Commercial malt culture (CMC) medium. Malt culture media (20 g/L) with $1 \mathrm{~g} / \mathrm{L}$ of yeast extract.

2.1.2.2. Mussel process wastewaters medium (MPWm). The MPW were kindly supplied by Marcelino S.A. (Galicia, Spain), and their chemical composition was as follows: $7 \mathrm{~g} / \mathrm{L}$ glycogen, $0.10 \mathrm{~g} / \mathrm{L}$ reducing sugars, $3.5 \mathrm{~g} / \mathrm{L}$ proteins and $1.6 \mathrm{~g} / \mathrm{L}$ total nitrogen. Sediments were not observed in these effluents, and the initial $\mathrm{pH}$ was 7.2. The effluents were clarified by centrifugation after acidification ( $5 \mathrm{~N} \mathrm{HCl}$ to $\mathrm{pH} 4.5)$ to precipitate the greater part of their protein content, and concentrated to $20 \mathrm{~g} / \mathrm{L}$ of glycogen by ultrafiltration with a $100 \mathrm{kDa}$ cut-off membrane (Gonzalez et al., 1992; Murado et al., 1993b).

Both media were supplemented with $400 \mathrm{mg} / \mathrm{L}$ of $\mathrm{P}\left(\mathrm{as} \mathrm{KH}_{2} \mathrm{PO}_{4}\right)$ and $1.2 \mathrm{mg} / \mathrm{L}$ of $\mathrm{N}$ (as $\mathrm{NaNO}_{3}$ and $\mathrm{NH}_{4} \mathrm{Cl}$, so that the relationship between the reduced and oxidized form of $\mathrm{N}$ was $0.8: 0.2$ ) then, they were sterilized in an autoclave with steam vapor during $60 \mathrm{~min}$. Afterwards, the $\mathrm{pH}$ was brought to an initial value of 6.0.

\subsubsection{Inoculum and growth culture conditions}

The inocula (vegetative cells in yeast and spores in microfungi) were incubated in slant in malt agar at $30{ }^{\circ} \mathrm{C}$ for $48-96 \mathrm{~h}$. Using a calibrated spectrophotometer analysis at $700 \mathrm{~nm}$, suspensions in sterile water were prepared, whereby a volume of $1 \mathrm{~mL}$ provided an initial population of $5 \times 10^{4}$ cells $/ \mathrm{mL}$ in $50 \mathrm{~mL}$ of CMC medium.

Microbial growths were conducted in $250 \mathrm{~mL}$ Erlenmeyer flasks with orbital shaking at $200 \mathrm{rpm}$. At appropriate times, post-incubated medium and biomass were separated by centrifugation (4000 $\mathrm{g} / 30 \mathrm{~min}$ ). The supernatant was used for the basic composition analysis (proteins, total and reducing sugars, nitrogen, chitin and amylolytic activity), and the biomass pellet was washed twice with distilled water, lyophilized and stored at $-18{ }^{\circ} \mathrm{C}$ until processing.

\subsubsection{Kinetic analysis}

The growth analysis was carried out by adjusting the values of the produced biomass to the logistic-growth equation (Verhulst, 1845):

$X(t)=\frac{K}{1+\exp \left(c-\mu_{m} \cdot t\right)} ; \quad c=\ln \left[\left(\frac{K}{X_{0}}\right)-1\right]$

where $X$ is the biomass $(\mathrm{g} / \mathrm{L})$ with $X_{0}$ and $K$ as initial and maximum values, respectively; $t$ the time ( $\mathrm{h}$ ) and $\mu_{m}$ the specific maximum growth rate $\left(h^{-1}\right)$. Other values of interest defined from Eq. (1) were the maximum growth rate $\left(v_{m}\right.$, in $\left.\mathrm{gL}^{-1} \mathrm{~h}^{-1}\right)$, the lag-phase $(\lambda$, in $\mathrm{h})$ and the time $(\tau$, in $\mathrm{h})$ corresponding to the production of the half-maximum biomass, which is obtained by considering $X=K / 2$ in model (1):

$v_{m}=\frac{K \cdot \mu_{m}}{4}$

$\lambda=\frac{c-2}{\mu_{m}}$

$\tau=\frac{c}{\mu_{m}}$

Yields of biomass were referred to the consumptions of both $\mathrm{T}_{\mathrm{S}}$ and $\mathrm{T}_{\mathrm{P}}$ and quantified as:

$Y_{\mathrm{X} / \mathrm{Ts}}=\frac{\Delta X}{\Delta T s}=\frac{X_{f}-X_{0}}{T s_{0}-T s_{f}}$ and $Y_{\mathrm{X} / \mathrm{Tp}}=\frac{\Delta X}{\Delta T p}=\frac{X_{f}-X_{0}}{T p_{0}-T p_{f}}$. 


\subsection{Cell walls extraction and treatment}

Production and subsequent biomass $\mathrm{CW}$ treatments were conducted following the diagram presented in Fig. 1. All fractions (except for the cytoplasmatic material, in which dialysis and lyophilization steps were omitted) were treated as follows: 1) dialysis with a cut-off membrane of $12 \mathrm{kDa}$ using $~ 50 \mathrm{~L}$ of distilled water; 2) lyophilization; 3) drying over $\mathrm{KOH}$ at $50{ }^{\circ} \mathrm{C} / 24 \mathrm{~h}$, gravimetric analysis and grinding; 4) determination of principal components (proteins, total and reducing sugars, nitrogen and chitin); 5) GC identification and quantification of the main monosaccharide components; and 6) quantification of the proportion of $\beta-D-1,3$ links via enzymatic analysis.

\subsubsection{Cell wall extraction}

For CW extraction, one of the practical methods was used (Kasahara et al., 1994; Prieto et al., 2011), which is based on the cell autolysis in an autoclave and the CW separation by centrifugation. However, due to the criticism raised (Dallies et al., 1998), concerning the lack of reproducibility and the variability of results due to an inefficient separation of the CW and partial hydrolysis of polysaccharides during the initial states of the heat treatment, this technique was slightly modified as follows: a) a suspension of $30 \mathrm{~g} / \mathrm{L}$ biomass in distilled water at $\mathrm{pH} 6.0$ (200 mM TRIS) was preheated $\left(80^{\circ} \mathrm{C}\right.$ to avoid the initial states) and autoclaved $120^{\circ} \mathrm{C} / 20 \mathrm{~min}$; b) the suspension was centrifuged, the sediment was re-suspended in distilled water at pH 6.0 (200 mM TRIS); c) ten treatments (different times of sampling) with a double volume of glass beads were performed to remove CW impurities as much as possible; and d) the solution was centrifuged. All supernatants were collected, representing the cytoplasm fraction (CIT), and the pellet fraction was taken as the CW fraction.

\subsubsection{Alkali treatment}

The treatment was carried out at a concentration of $10 \mathrm{~g} / \mathrm{L}$, with $1 \mathrm{M}$ $\mathrm{KOH}$ in a predominantly nitrogenous environment for $24 \mathrm{~h}$ with gentle magnetic stirring. The suspension was centrifuged and the pellet was re-extracted at two consecutive times during $2 \mathrm{~h}$ under the same conditions. The supernatants were taken as the alkali-soluble fraction (AS), and the sediments as the alkali-insoluble fraction (AI). The temperature effect of the process was analyzed in detail at $10,30,50$, 70 and $90{ }^{\circ} \mathrm{C}$.

\subsubsection{Acid treatment}

The treatment was carried out at a concentration of $20 \mathrm{~g} / \mathrm{L}$, with $1 \mathrm{M}$ acetic acid at $90{ }^{\circ} \mathrm{C}$ for 90 min with magnetic stirring. Sediment and supernatant were separated as in the previous point and the process was repeated two times. The supernatants collected are considered as the alkali-insoluble acid soluble fraction (AIAS) and the sediment as the alkali-insoluble acid-insoluble (AIAI).

\subsection{4. $\mathrm{pH}$ precipitation}

The treatment was carried out adding $\mathrm{HCl}(50 \% \mathrm{w} / \mathrm{v})$ to the AS fraction until the $\mathrm{pH}$ reached a value of 4.5 , at which most of the protein content can be removed easily by centrifugation. The sediment fraction is named as $\mathrm{ASpH}$ and the supernatant is used in the next purifying step.

\subsubsection{Alcohol precipitation}

The above supernatant was treated with two volumes of ethanol followed by centrifugation. The discarded supernatant and sediment fraction is named as ASET.

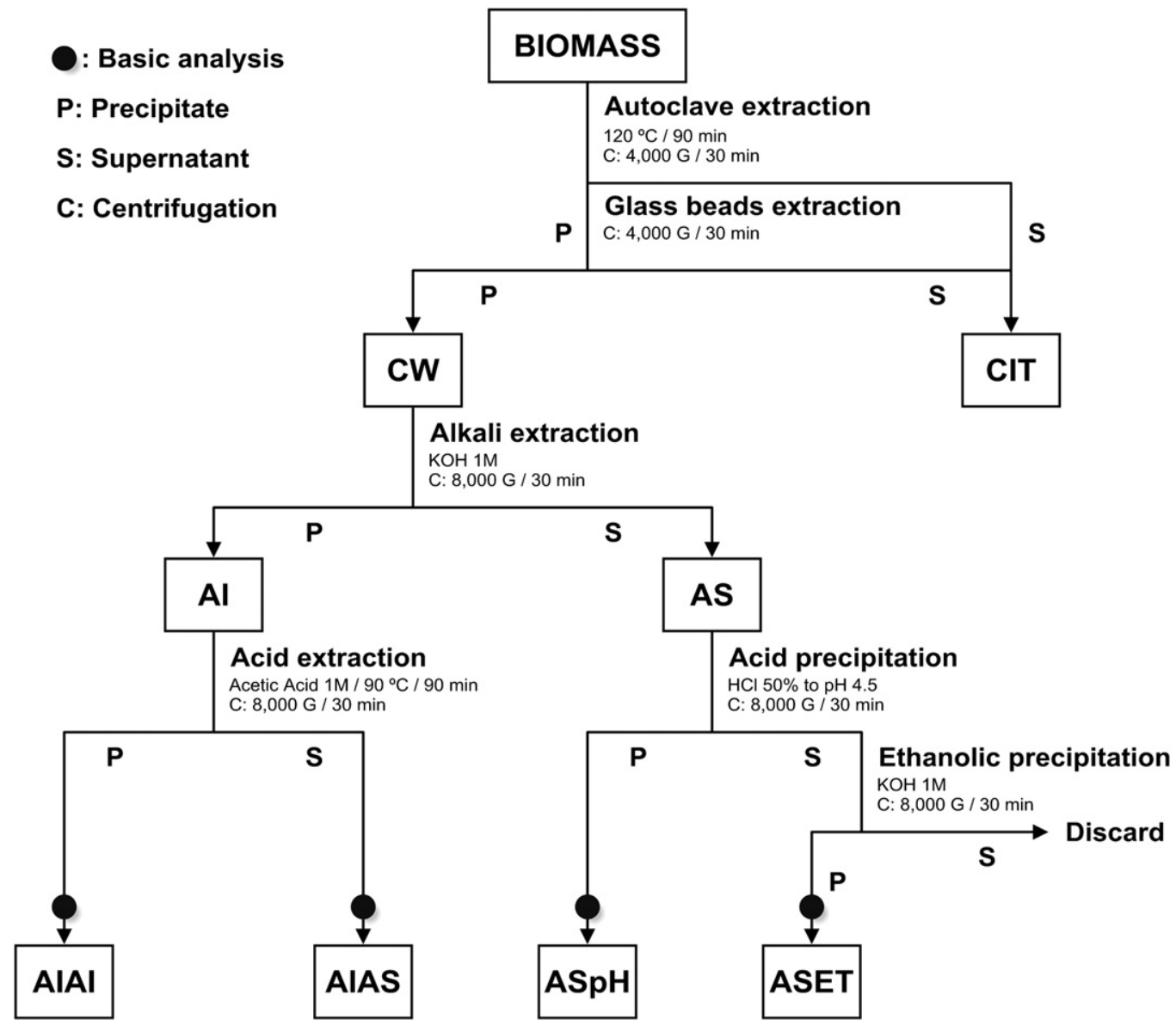

Fig. 1. A schematic summary of the methodological procedure of the chemical treatment of biomass to obtain several fractions. 


\subsection{Basic analytical methods}

Dry solids $\left(\mathrm{D}_{\mathrm{W}}\right)$ and ashes $(\mathrm{Cz})$ were conducted following the common procedures reported by Mortensen et al. (1989). Total sugar $\left(\mathrm{T}_{\mathrm{S}}\right)$ using the phenol-sulfuric method (Dubois et al., 1956) and reducing sugars $\left(\mathrm{R}_{\mathrm{S}}\right)$ by the dinitrosalicylic acid method (DNS) according to Bernfeld (1951), in both with glucose:mannose (0.6:0.4). Total proteins $\left(T_{P}\right)$ with the method was developed by Lowry et al. (1951). Total nitrogen $(N t)$ by the Kjeldahl method and quantified by the spectrophotometer method was developed by Havilah et al. (1977). Total hexosamines $\left(T_{H}\right)$ following the method was described by Dallies et al. (1998) with $\mathrm{N}$-acetylglucosamine as standard. Fatty acids (FA) by gravimetric difference between the extracted and non-extracted residue in Soxhlet with ether (Manirakiza et al., 2001). Total amylolytic activity (AAT) was determined using the $R_{S}$ production from starch following the description of Miranda et al. (1987). The monosaccharide determination by gas chromatography (GC) was conducted following the work of Prieto et al. (2011).

\subsection{Enzymatic determination of glycoside linkages $\beta-D-1,3$}

The analysis was conducted with the commercial enzyme product $\beta$-D-1,3 glucanase Glucanex® 200G (Novozymes) following the method described by Prieto et al. (2012). Laminarin and curdlan, with $100 \%$ and $66.6 \%$ of $\beta$-D-1,3 links respectively, were used as standards. The results were fitted to the following first order kinetic model:

$H=H_{m}\left(1-e^{-r t}\right)$

where $H$ is the concentration of reducing sugars (\%) at a given time $t, r$ the specific rate of hydrolysis $\left(t^{-1}\right)$ and $H_{m}$ the maximum proportion of $\beta$-D-1,3 links present in the sample (\%).

\subsection{Antioxidant activity determination}

Four different methods were applied to test the antioxidant activity (AA) of the samples obtained: The 2,2-diphenylpicrylhydrazyl (DPPH) and 2,2-azino-bis/3-ethil-benothiazoline-6-sulfonic acid (ABTS) assays following the indications of Serpen et al. (2007) as well as the $\beta$-carotene $(\beta C)$ and Crocin $(\mathrm{Cr})$ bleaching assays as described by Prieto et al. (2013). For the DPPH and ABTS methods (hydrophilic reactions), the calculation procedure of antioxidant equivalents $\left(e q v_{A}\right)$ of the samples was based on a kninetic determinations using the commercial compound Trolox as reference antioxidant. In the $\beta C$ (lipophilic reaction) and $\mathrm{Cr}$ (hydrophilic reaction) bleaching assays, the calculation procedure is based on kinetic measures, in which the antioxidant action of the profile is computed as the area under the curve used (Dávalos, 2004; Naguib, 2000) and the eqv $v_{A}$ is computed using a reference antioxidant of butylated hydroxytoluene (BHT) for the $\beta C$ reaction and butylated hydroxyanisole (BHA) for Cr. For comparative purpose, AA of different commercial polysaccharides (curdlan and laminarin), peptone (tryptone) and yeast extract were also measured.

\subsection{Numerical methods}

Fitting of the experimental results to the proposed equations was carried out in two phases: First, parametric estimates were obtained by minimization of the sum of quadratic differences between observed and model-predicted values, using the nonlinear least-squares (quasi-Newton) method (Kemmer and Keller, 2010) provided by the macro Solver of Microsoft Excel 2003 spreadsheet. It allows quick testing of hypotheses and display of its consequences. Subsequently, the determination of the parametric confidence intervals and model consistency (Student's $t$ and Fisher's $F$ tests, respectively, in both cases with $\alpha=$ 0.05 ) were calculated using the 'SolverAid' macro (Murado and Prieto, 2013a; Prikler, 2009)

\section{Results and discussion}

\subsection{Microbial growth: strains selection, temperature effect and residual media application}

Table 1 lists the values of the kinetic parameters and the statistical analyses of the numerical fitting results for all the microbial growth tests. In all cases, the models were statistically robust ( $p$-values for Fisher's F-test $<0.05)$, the parametric estimations were significant (Student's $t$-test $\alpha=0.05$ ) and the residuals were randomly distributed. The linear determination coefficients $\left(r^{2}\right)$ between the predicted and observed values were always higher than 0.97 .

\subsubsection{Strain selection}

For the strain selection process the following results were used: (a) the kinetic analysis of biomass and post-incubated composition (Fig. 2 and Table 1) and (b) the data obtained from the compositional analysis of biomass at $55 \mathrm{~h}$ of incubation as a comparison system for the different microorganisms tested on the CMC medium (Tables 2 and 3). Attending to the kinetic parameters from Table 1, the preferable descending order can be established as follows: Ao $>\mathrm{Sf}>\mathrm{An}>\mathrm{Sc}>\mathrm{Rr}$ for $K$; $\mathrm{Ao}>\mathrm{Sf}>\mathrm{Rr}>\mathrm{An}>\mathrm{Sc}$ for $\mu_{m} ; \mathrm{Ao}>\mathrm{Sf}>\mathrm{An}>\mathrm{Rr}>\mathrm{Sc}$ for $v_{m}$. According to $\lambda$ and $\tau$, the descending order should be $\mathrm{Rr}>\mathrm{Sc}>\mathrm{Sf}>\mathrm{An}>\mathrm{Ao}$. In relation to the production yields, the following preferable descending order for strains was found: $\mathrm{Sc}>\mathrm{Rr}>\mathrm{Ao}>\mathrm{Sf}>\mathrm{An}\left(Y_{\mathrm{X} / T_{S}}\right)$ and

Table 1

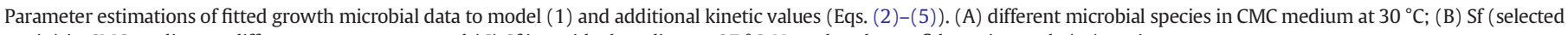
strain) in CMC medium at different temperatures; and (C) Sf in residual medium at $27^{\circ} \mathrm{C}$. Note that the confidence intervals $( \pm)$ are in percentages.

\begin{tabular}{|c|c|c|c|c|c|c|c|c|c|}
\hline & \multicolumn{7}{|c|}{ Kinetic analysis } & \multicolumn{2}{|l|}{ Yields } \\
\hline & $K$ & $c$ & $\mu_{m}$ & $v_{m}$ & $\lambda$ & $\tau$ & $r^{2}$ & $Y_{\mathrm{X} / T_{S}}$ & $Y_{\mathrm{X} / T_{P}}$ \\
\hline \multicolumn{10}{|c|}{ (A) Different microbial species in $C M C$ medium at $30^{\circ} \mathrm{C}$} \\
\hline Sf & $9.85 \pm 2.0$ & $0.162 \pm 11.5$ & $4.47 \pm 11.2$ & $0.399 \pm 10,8$ & $15.25 \pm 9,5$ & $27.61 \pm 12,5$ & 0.9981 & 0.482 & 2.711 \\
\hline An & $8.94 \pm 2.4$ & $0.152 \pm 11.4$ & $5.17 \pm 10.5$ & $0.340 \pm 10,4$ & $20.86 \pm 6,7$ & $34.01 \pm 12,4$ & 0.9981 & 0.431 & 2.850 \\
\hline Ao & $10.44 \pm 3.7$ & $0.180 \pm 20.5$ & $5.89 \pm 19.3$ & $0.469 \pm 19,1$ & $21.65 \pm 9,9$ & $32.79 \pm 25,1$ & 0.9951 & 0.504 & 2.842 \\
\hline Sc & $7.23 \pm 3.0$ & $0.134 \pm 16.1$ & $3.42 \pm 16.0$ & $0.242 \pm 15,0$ & $10.58 \pm 22,8$ & $25.50 \pm 14,9$ & 0.9957 & 0.531 & 2.879 \\
\hline $\mathrm{Rr}$ & $6.70 \pm 2.1$ & $0.158 \pm 13.0$ & $3.55 \pm 13.6$ & $0.264 \pm 12,3$ & $9.80 \pm 19,1$ & $22.49 \pm 13,7$ & 0.9974 & 0.513 & 2.820 \\
\hline \multicolumn{10}{|c|}{ (B) Sf (selected strain) in CMC medium at different temperatures } \\
\hline $21{ }^{\circ} \mathrm{C}$ & $5.93 \pm 5.6$ & $0.103 \pm 22.6$ & $4.64 \pm 19.6$ & $0.153 \pm 20,0$ & $25.58 \pm 13,7$ & $44.93 \pm 17,5$ & 0.9941 & 0.465 & 2.062 \\
\hline $24^{\circ} \mathrm{C}$ & $7.24 \pm 9.3$ & $0.110 \pm 42.5$ & $3.74 \pm 40.3$ & $0.198 \pm 27,1$ & $15.88 \pm 31,1$ & $34.12 \pm 33,4$ & 0.9855 & 0.488 & 2.578 \\
\hline $27^{\circ} \mathrm{C}$ & $10.11 \pm 4.2$ & $0.154 \pm 23.8$ & $3.95 \pm 22.3$ & $0.389 \pm 19,8$ & $12.68 \pm 21,0$ & $25.68 \pm 24,7$ & 0.9940 & 0.498 & 3.552 \\
\hline $30{ }^{\circ} \mathrm{C}$ & $9.59 \pm 6.7$ & $0.152 \pm 34.7$ & $3.79 \pm 33.1$ & $0.364 \pm 35,7$ & $11.81 \pm 41,3$ & $24.99 \pm 36,5$ & 0.9793 & 0.476 & 3.740 \\
\hline $33^{\circ} \mathrm{C}$ & $9.36 \pm 8.2$ & $0.115 \pm 42.2$ & $3.03 \pm 42.9$ & $0.270 \pm 30,4$ & $8.92 \pm 60,5$ & $26.24 \pm 33,9$ & 0.9808 & 0.451 & 3.623 \\
\hline \multicolumn{10}{|c|}{ (C) Sf in residual medium at $27^{\circ} \mathrm{C}$ (selected temperature) } \\
\hline Sf & $12.37 \pm 5.9$ & $0.126 \pm 30.7$ & $3.19 \pm 27.9$ & $0.391 \pm 26.3$ & $9.383 \pm 39.2$ & $25.22 \pm 27.4$ & 0.9956 & 0.589 & 5.890 \\
\hline
\end{tabular}


Sc $>$ An $>$ Ao $>$ Rr $>$ Sf $\left(Y_{\mathrm{X} / T_{\mathrm{Pr}}}\right)$. Considering the \% Glu $\beta-D-1,3$ links (Table 2 and Fig. 3), the decreasing selection order would be: in reference to the $X \mathrm{An}>\mathrm{Ao}>\mathrm{Sf}>\mathrm{Sc}>\mathrm{Rr}$ and in reference to the $\mathrm{CW}$ An $>$ Ao $>$ Sf $>$ Sc $>$ Rr.

Since the purpose is to purify wastewater effluents that contain glycogen as the main carbon source, another significant criterion is the ability to produce enzymes capable of hydrolyzing this polysaccharide. Two groups of microbial species can be established, those capable of producing hydrolytic enzymes that consumes polysaccharides present in the medium ( $\mathrm{Sf}, \mathrm{An}$ and $\mathrm{Ao}$ ) and those without ( $\mathrm{Sc}$ and $\mathrm{Rr}$ ). Moreover, cell lysis to obtain CW was simpler for yeasts (Sf, Sc or Rr) than fungi (An or Ao).
Consequently, the yeast Sf (S. fibuligera) was the final microorganism selected because: (1) it was the second strain in terms of productions and yields and has a higher content of $\mathrm{T}_{\mathrm{S}} / \mathrm{X} ;(2)$ is capable of producing enzymes that hydrolyze the main source of carbon (glycogen) present in the mussel effluents; and (3) reduces the complexity of the process and facilitates cell mass production.

\subsubsection{Temperature effect on the Sf growth}

Under the conditions provided in the materials and methods section, we have tested the effect of temperature on the growth behavior of Sf in the CMC medium. After previous assessments (data not shown), we selected the temperature range $\left(20\right.$ to $35^{\circ} \mathrm{C}$ ) that produces a cell growth

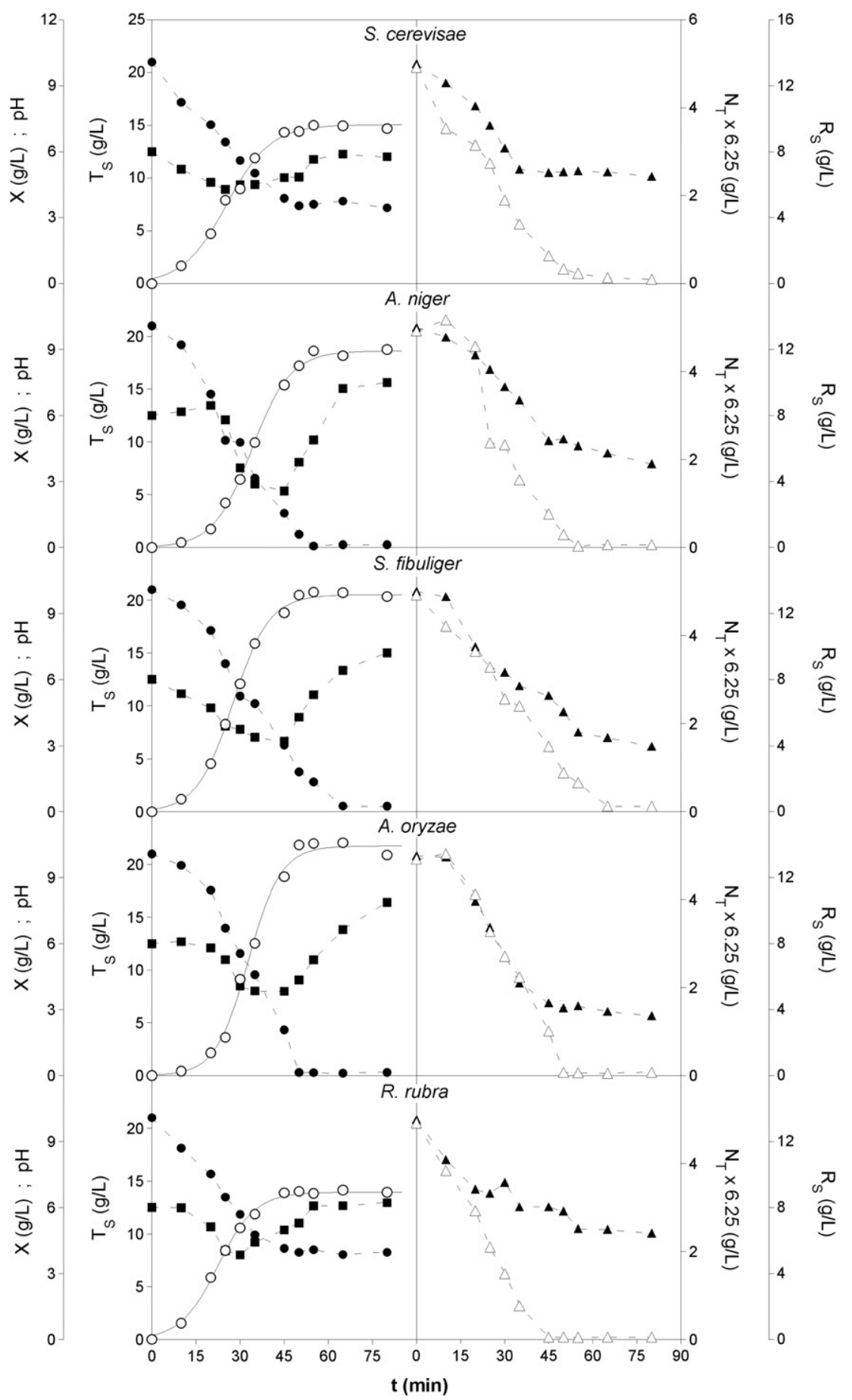

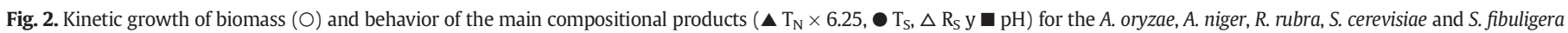
fermented in $\mathrm{CMC}$ medium at $30^{\circ} \mathrm{C}$. 
Table 2

Compositional values (\%) of different microbial species analyzed in CMC (A) and MPWm (B) medium. Note that the confidence intervals $( \pm)$ are in percentages.

\begin{tabular}{|c|c|c|c|c|c|c|c|c|}
\hline \multirow[t]{3}{*}{ Strains } & \multicolumn{8}{|c|}{ Compositional analysis } \\
\hline & \multirow{2}{*}{$\begin{array}{l}C_{Z} \\
\% C_{Z} \\
X^{-1}\end{array}$} & \multirow{2}{*}{$\begin{array}{l}\frac{\mathrm{R}_{\mathrm{S}}}{\% \mathrm{R}_{\mathrm{S}}} \\
X^{-1}\end{array}$} & \multirow{2}{*}{$\begin{array}{l}\frac{\mathrm{T}_{\mathrm{S}}}{\% \mathrm{~T}_{\mathrm{S}}} \\
X^{-1}\end{array}$} & \multirow{2}{*}{$\begin{array}{l}\frac{\mathrm{T}_{\mathrm{P}}}{\% \mathrm{~T}_{\mathrm{P}}} \\
X^{-1}\end{array}$} & \multirow{2}{*}{$\begin{array}{l}\frac{\mathrm{T}_{\mathrm{N}} \times 6.25}{\% \mathrm{~T}_{\mathrm{N}}} \\
X^{-1}\end{array}$} & \multirow{2}{*}{$\begin{array}{l}\frac{\mathrm{F}_{\mathrm{A}}}{\% \mathrm{~F}_{\mathrm{A}}} \\
X^{-1}\end{array}$} & \multirow{2}{*}{$\frac{\mathrm{T}_{\mathrm{H}}}{\% \mathrm{~T}_{\mathrm{H}}}$} & \multirow{2}{*}{$\begin{array}{l}\frac{\beta-\mathrm{D}-1,3}{\% \beta-D-1,3 \mathrm{~T}} \\
\mathrm{CW}^{-1}\end{array}$} \\
\hline & & & & & & & & \\
\hline \multicolumn{9}{|c|}{ (A) Different microbial species analyzed in $\mathrm{CMC}$ medium at $30^{\circ} \mathrm{C}$} \\
\hline Sf & 9.75 & 3.86 & 47.72 & 29.40 & 37.85 & 1.29 & 1.63 & $41.29 \pm 2.3$ \\
\hline An & 8.77 & 5.67 & 43.98 & 35.62 & 51.43 & 1.09 & 3.41 & $44.08 \pm 0.2$ \\
\hline Ao & 10.45 & 3.23 & 33.69 & 40.98 & 50.67 & 1.56 & 2.78 & $43.82 \pm 0.1$ \\
\hline Sc & 5.05 & 4.89 & 39.25 & 33.98 & 45.90 & 0.65 & 0.98 & $27.40 \pm 0.4$ \\
\hline $\mathrm{Rr}$ & 5.98 & 5.45 & 40.89 & 28.98 & 43.43 & 1.45 & 1.21 & $18.22 \pm 0.9$ \\
\hline \multicolumn{9}{|c|}{ (B) S. fibuligera in residual medium at $27^{\circ} \mathrm{C}$} \\
\hline Sf & 9.42 & 6.93 & 51.03 & 28.33 & 35.11 & 1.05 & 1.44 & $44.91 \pm 3.1$ \\
\hline
\end{tabular}

at the top of the bell activation-inhibition (Rosso et al., 1993). Fig. 4 and Table 1 show the results, in which the key aspects are summarized: (1) at temperatures of $33^{\circ} \mathrm{C}$ or higher, the maximum biomass production $(K)$ is reduced although $\mu_{m}$ increases and $\lambda$ decreases; and (2) $\mu_{m}$ and $K$ decrease while $\lambda$ increases when T decreases from $27^{\circ} \mathrm{C}$. Thus, the authors found the range from 27 to $30^{\circ} \mathrm{C}$ as the optimal conditions. Within this range of temperatures, we finally choose the option of $27^{\circ} \mathrm{C}$ due to its best parameter results and the reduction of production costs when scaling-up for industrial purposes.

\subsubsection{Growth in MPW media. SCP production}

When we applied the above selected conditions to the MPWm (Fig. 4 bottom), all the kinetic parameters and yields (Table 1 ) as well as the $T_{S}$ improved, obtaining higher values than those produced under the same conditions in the CMC medium (Table 2). At $55 \mathrm{~h}$, the biomass exhibits its maximum growth with $12 \mathrm{~g} / \mathrm{L}$ (as dry weight). At that time, the glycogen from the residual culture media was completely consumed, the pH increased from 5.3 to 6.8 and the yeast amylases were no longer produced. Therefore, we selected the culture time of $55 \mathrm{~h}$ to collect the biomass. This biomass was then used for the compositional analyses and CW hydrolysis, Table 2 shows the chemical composition of the microbial species, of which we want to highlight to the reader the $51 \%$ of total sugars and the $28 \%$ of proteins.

\subsection{CW extraction and separation}

\subsubsection{Chemical separation of cell walls, yields and composition}

The extraction of the CW by the combination of both treatments (autoclave and glass beads) may not be as efficient as other more laborious methods (Dallies et al., 1998), but produces stable and comparable fractions and is more suitable for application in industrial processes. First part of Table 3 and Fig. 3 shows the results of the compositional analysis of Sf fermented on MPWm. The CW obtained exhibits a whitish color with slight brownish tone, which is attributed to the protein content in the $\mathrm{CW}$, mostly covalently bonded to mannan molecules (Nguyen et al., 1998). The CW rigidity is attributed to the presence of 1,3-B-D-glucan links (Fleet and Phaff, 1974) that would form a threedimensional platform that provides the structural basis of CW. We want to emphasize the $64 \%$ of total sugars composition of $\mathrm{CW}$, a value that is higher than those reported in the bibliography (Nguyen et al., 1998).

\subsubsection{Alkaline treatment. Optimization and performance}

In general, most of the studies focus on the insoluble glucan fraction (Hunter et al., 2002) due to their properties as stimulators of the immune system, reducing agents of cholesterol level in blood stream, antitumor activity and application in cosmetic products (Nguyen et al., 1998). In addition, recently the food industry has shown interest in the soluble glucan fractions as fattening agents or as sources of dietary fiber. Apparently the solubility or insolubility of the glucan fraction is closely related to the presence of the $\beta(1 \rightarrow 6)$ links (Bacon et al., 1969).

For CW chemical separation, the alkaline treatment is commonly the first step applied, obtaining the following fractions (Fig. 1): AS composed mainly of soluble glucans, mannans, proteins and lipids; and AI composed of insoluble glucans and chitin. The temperature and the molarities applied in the treatment are the key factors for its optimization.

Table 3

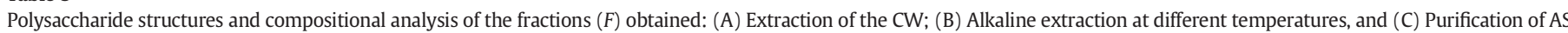

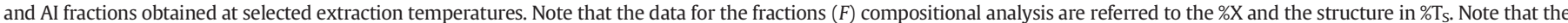
confidence intervals $( \pm)$ are in percentages.

\begin{tabular}{|c|c|c|c|c|c|c|c|c|}
\hline \multicolumn{2}{|l|}{ Fractions } & \multicolumn{4}{|c|}{ Compositional analysis (\%) } & \multicolumn{3}{|c|}{ Sugar composition } \\
\hline \multirow[t]{2}{*}{ 2Treated } & \multirow[t]{2}{*}{ Obtained } & $\mathrm{D}_{\mathrm{W}}$ & $\mathrm{T}_{\mathrm{S}}$ & $\mathrm{T}_{\mathrm{N}} \times 6.25$ & $\mathrm{~T}_{\mathrm{H}}$ & Glu & Man & $\beta-D-1.3$ \\
\hline & & $\% g F / g X$ & $\% T_{S} F / T_{S} X$ & $\% T_{N} F / N_{T} X$ & $\% T_{H} F / H_{T} X$ & $\% G l u / T_{S} F$ & $\% \operatorname{Man} / T_{S} F$ & $\% \beta-D-1.3 / T_{S} F$ \\
\hline \multicolumn{9}{|c|}{ (A) Cell wall treatment } \\
\hline & CIT & $37.36 \pm 5.0$ & $38.49 \pm 4.8$ & $33.07 \pm 3.5$ & - & $95.35 \pm 4.2$ & $4.65 \pm 3.6$ & - \\
\hline & $\mathrm{CW}$ & $55.56 \pm 6.3$ & $64.06 \pm 6.8$ & $53.92 \pm 6.0$ & $96.23 \pm 5.4$ & $62.12 \pm 3.7$ & $37.88 \pm 5.5$ & $44.91 \pm 3.1$ \\
\hline \multicolumn{9}{|c|}{ (B) Alkali treatment and temperature effect } \\
\hline \multirow{2}{*}{$\mathrm{CW}\left(10^{\circ} \mathrm{C}\right)$} & $\mathrm{AI}$ & $23.93 \pm 1.8$ & $35.42 \pm 1.7$ & $9.33 \pm 1.8$ & $90.92 \pm 0.9$ & $80.72 \pm 3.8$ & $19.28 \pm 0.5$ & $41.25 \pm 2.5$ \\
\hline & AS & $24.41 \pm 1.6$ & $26.21 \pm 1.6$ & $31.22 \pm 0.5$ & - & $50.43 \pm 3.6$ & $49.56 \pm 0.2$ & $24.97 \pm 3.2$ \\
\hline \multirow[t]{2}{*}{$\mathrm{CW}\left(30^{\circ} \mathrm{C}\right)$} & AI & $20.81 \pm 3.5$ & $31.01 \pm 2.4$ & $7.98 \pm 2.6$ & $90.31 \pm 1.9$ & $84.78 \pm 1.7$ & $15.22 \pm 1.8$ & $48.98 \pm 1.3$ \\
\hline & AS & $25.91 \pm 8.9$ & $27.76 \pm 1.8$ & $32.18 \pm 0.6$ & - & $46.09 \pm 1.7$ & $53.91 \pm 3.4$ & $22.36 \pm 1.4$ \\
\hline \multirow[t]{2}{*}{$\mathrm{CW}\left(50^{\circ} \mathrm{C}\right)$} & $\mathrm{AI}$ & $17.27 \pm 5.8$ & $26.61 \pm 4.4$ & $6.43 \pm 5.0$ & $80.91 \pm 1.2$ & $87.67 \pm 7.2$ & $12.33 \pm 1.1$ & $63.48 \pm 0.5$ \\
\hline & AS & $30.34 \pm 2.3$ & $32.40 \pm 2.1$ & $32.83 \pm 4.0$ & - & $41.24 \pm 5.2$ & $58.75 \pm 3.1$ & $16.25 \pm 2.1$ \\
\hline \multirow[t]{2}{*}{$\mathrm{CW}\left(70^{\circ} \mathrm{C}\right)$} & AI & $8.27 \pm 2.6$ & $8.39 \pm 2.1$ & $1.85 \pm 0.8$ & $71.52 \pm 0.6$ & $91.06 \pm 2.3$ & $8.94 \pm 1.8$ & $72.65 \pm 0.6$ \\
\hline & AS & $36.60 \pm 1.3$ & $40.40 \pm 5.7$ & $36.33 \pm 5.7$ & - & $36.50 \pm 5.3$ & $63.50 \pm 1.3$ & $10.88 \pm 0.8$ \\
\hline \multirow[t]{2}{*}{$\mathrm{CW}\left(90^{\circ} \mathrm{C}\right)$} & $\mathrm{AI}$ & $6.64 \pm 1.1$ & $6.96 \pm 1.6$ & $1.33 \pm 6.9$ & $68.19 \pm 1.1$ & $91.35 \pm 2.2$ & $8.65 \pm 2.6$ & $78.95 \pm 0.6$ \\
\hline & AS & $41.20 \pm 1.1$ & $43.60 \pm 5.4$ & $35.56 \pm 0.3$ & - & $34.14 \pm 2.2$ & $65.85 \pm 3.2$ & $7.67 \pm 0.6$ \\
\hline \multicolumn{9}{|c|}{ (C) Purification treatments at the selected temperatures } \\
\hline \multirow[t]{4}{*}{$\mathrm{CW}\left(10^{\circ} \mathrm{C}\right)$} & AIAI & $19.54 \pm 4.2$ & $21.90 \pm 2.1$ & $17.55 \pm 2.9$ & $84.07 \pm 0.9$ & $85.40 \pm 8.7$ & $14.60 \pm 7.7$ & $35.35 \pm 2.6$ \\
\hline & AIAS & $3.30 \pm 4.9$ & $4.58 \pm 1.5$ & $2.24 \pm 2.8$ & - & $87.24 \pm 6.0$ & $12.76 \pm 2.1$ & $11.88 \pm 0.8$ \\
\hline & ASpH & $2.93 \pm 5.0$ & $0.44 \pm 1.5$ & $6.99 \pm 1.6$ & - & $31.97 \pm 5.7$ & $68.03 \pm 6.5$ & $5.02 \pm 1.6$ \\
\hline & ASET & $17.27 \pm 2.3$ & $26.14 \pm 1.1$ & $7.26 \pm 3.1$ & - & $65.51 \pm 2.3$ & $34.49 \pm 2.2$ & $12.79 \pm 0.9$ \\
\hline \multirow[t]{4}{*}{$\mathrm{CW}\left(70^{\circ} \mathrm{C}\right)$} & AIAI & $5.64 \pm 6.4$ & $6.67 \pm 2.7$ & $3.87 \pm 2.6$ & $68.40 \pm 0.5$ & $96.45 \pm 2.8$ & $3.55 \pm 2.7$ & $77.05 \pm 6.3$ \\
\hline & AIAS & $0.77 \pm 4.2$ & $1.11 \pm 2.0$ & $0.34 \pm 2.9$ & - & $85.25 \pm 6.5$ & $14.75 \pm 4.5$ & $7.37 \pm 1.1$ \\
\hline & ASpH & $9.40 \pm 3.9$ & $5.48 \pm 2.6$ & $17.57 \pm 1.9$ & - & $21.97 \pm 1.4$ & $78.03 \pm 7.7$ & $3.05 \pm 0.3$ \\
\hline & ASET & $26.43 \pm 1.4$ & $37.74 \pm 0.4$ & $12.84 \pm 2.6$ & - & $59.20 \pm 1.4$ & $40.80 \pm 5.8$ & $7.31 \pm 0.4$ \\
\hline
\end{tabular}



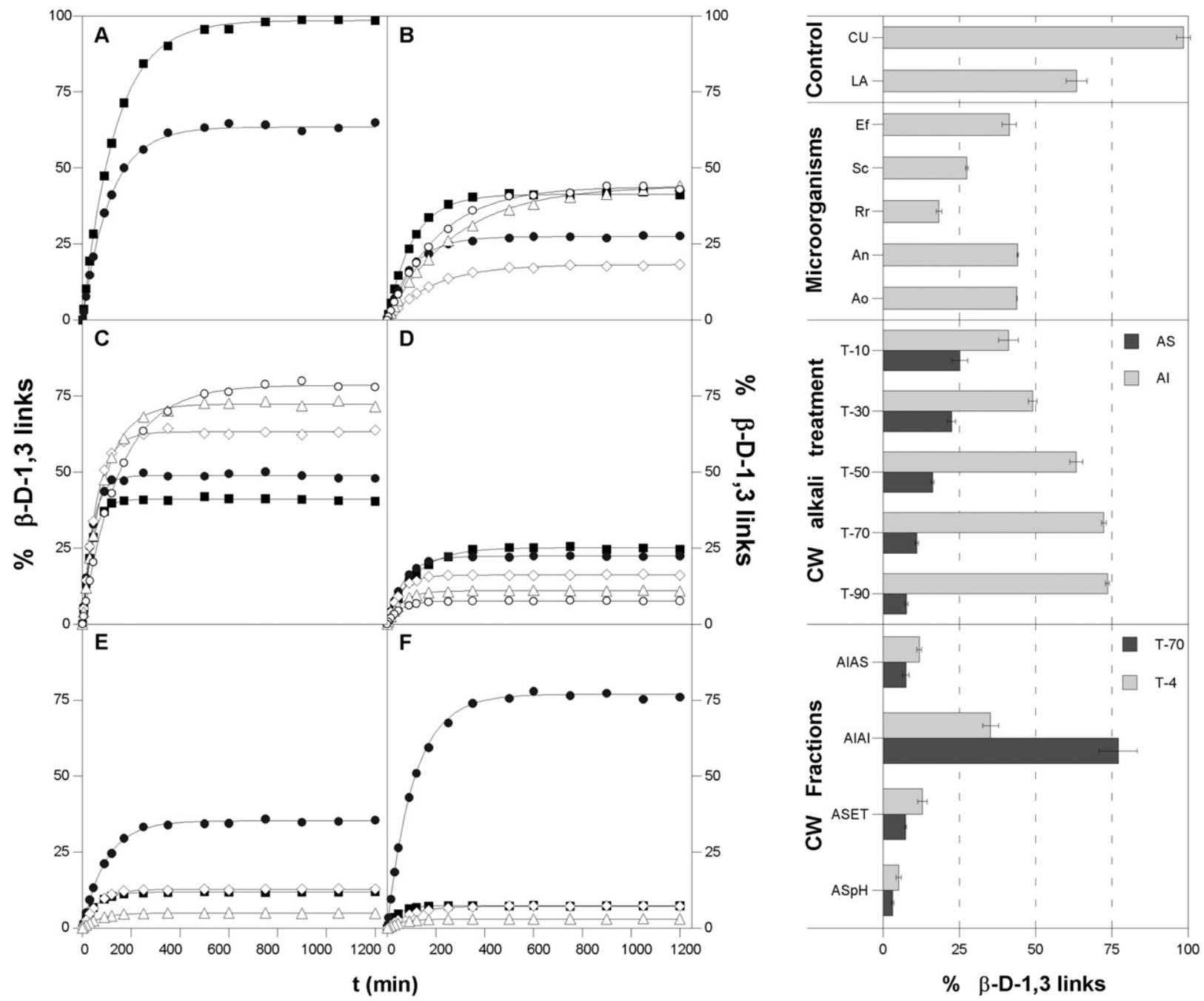

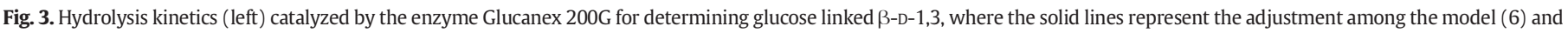

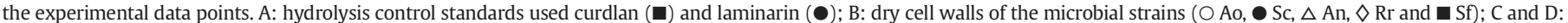

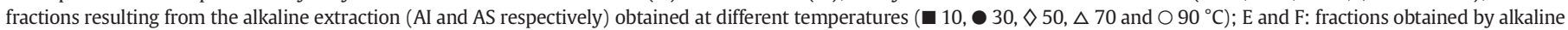

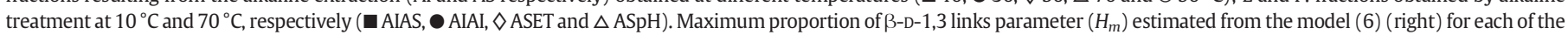
analyzed samples.

When the alkali treatment is ineffective, different proportions of proteins and polysaccharides of mannan are found in the AI fraction. Most processes agree relatively well on the alkali concentration using a range between 0.5 and $1.5 \mathrm{M}$. However, in relation to the temperature of the process, authors use a diverse range (from 4 to $120^{\circ} \mathrm{C}$ ). In general, the process should be effective, but also should avoid the deterioration of the resulting fractions, preserve the properties and facilitate its use in industrial applications. Therefore, to simplify the analysis, the alkali concentration was fixed to a $1 \mathrm{M} \mathrm{KOH}$ value and the effect of T (10, $30,50,70$ and $90^{\circ} \mathrm{C}$ ) was assessed in detail (Table 3).

The increase of $\mathrm{T}$ caused a decrease in the total $\mathrm{D}_{\mathrm{W}}$ of the AI fraction and in the proportion of $\mathrm{T}_{\mathrm{S}} / \mathrm{AI}$, as well as an almost proportional increase in the AS fraction. Overall, the recovery rate does not undergo significant changes between the two fractions obtained with 47\% of the initial biomass $\left(g / g D_{W}\right)$. The $T_{H}$ (mainly chitin) showed a decrease as the $\mathrm{T}$ increases, which is attributable to the thermo-alkaline deacetylation of the $\mathrm{N}$-acetylglucosamine links (chitosan), which is not detected by the $\mathrm{T}_{\mathrm{H}}$ method or by determining $\mathrm{T}_{\mathrm{S}}$. As $\mathrm{T}$ increases the remaining proteins $\left(\mathrm{T}_{\mathrm{N}}\right)$ move from the AS to the AI fraction. The proportion of $\beta-\mathrm{D}-1,3$ links and the presence of glucose monosaccharide increases in the AI fraction at higher T. Moreover, the proportion of mannans increases in the AS fraction as the $\mathrm{T}$ of the extraction increases.
In general, $\mathrm{T}$ affects the $\mathrm{AI}$ fraction by increasing the proportion of polysaccharides of glucose with $\beta$-D-1,3 links, solubilizing the protein and polysaccharides of mannans - probably as part of larger structures (mannoproteins) - to the AS fraction. Thus, we have considered two possible temperatures for further purification steps, at low $\mathrm{T}\left(10^{\circ} \mathrm{C}\right.$, cheaper but inefficient) and at high $\mathrm{T}\left(70{ }^{\circ} \mathrm{C}\right.$, more expensive but effective), because the comparison of the product yields may be of interest for the reader.

\subsection{Purification steps}

Some industrial sectors may introduce directly the insoluble and soluble fractions obtained. However, with some chemical, mechanical or enzymatic treatments, these fractions could be purified for other purposes. In this work, we explored the basic purifications processes: an acid treatment for the AI fraction and a $\mathrm{pH}$ and ethanol precipitation treatment for the AS fraction. Table 3 summarizes the compositional analysis of the obtained fractions and next we will discuss the relevant aspects.

\subsubsection{Purification of the AI fraction. Isolation of $1,3-\beta$-glucans fraction}

$\beta$-glucans are the majority of the compounds conforming the AI fraction. Their structure is formed by polysaccharides of $\beta(1 \rightarrow 3)$ 

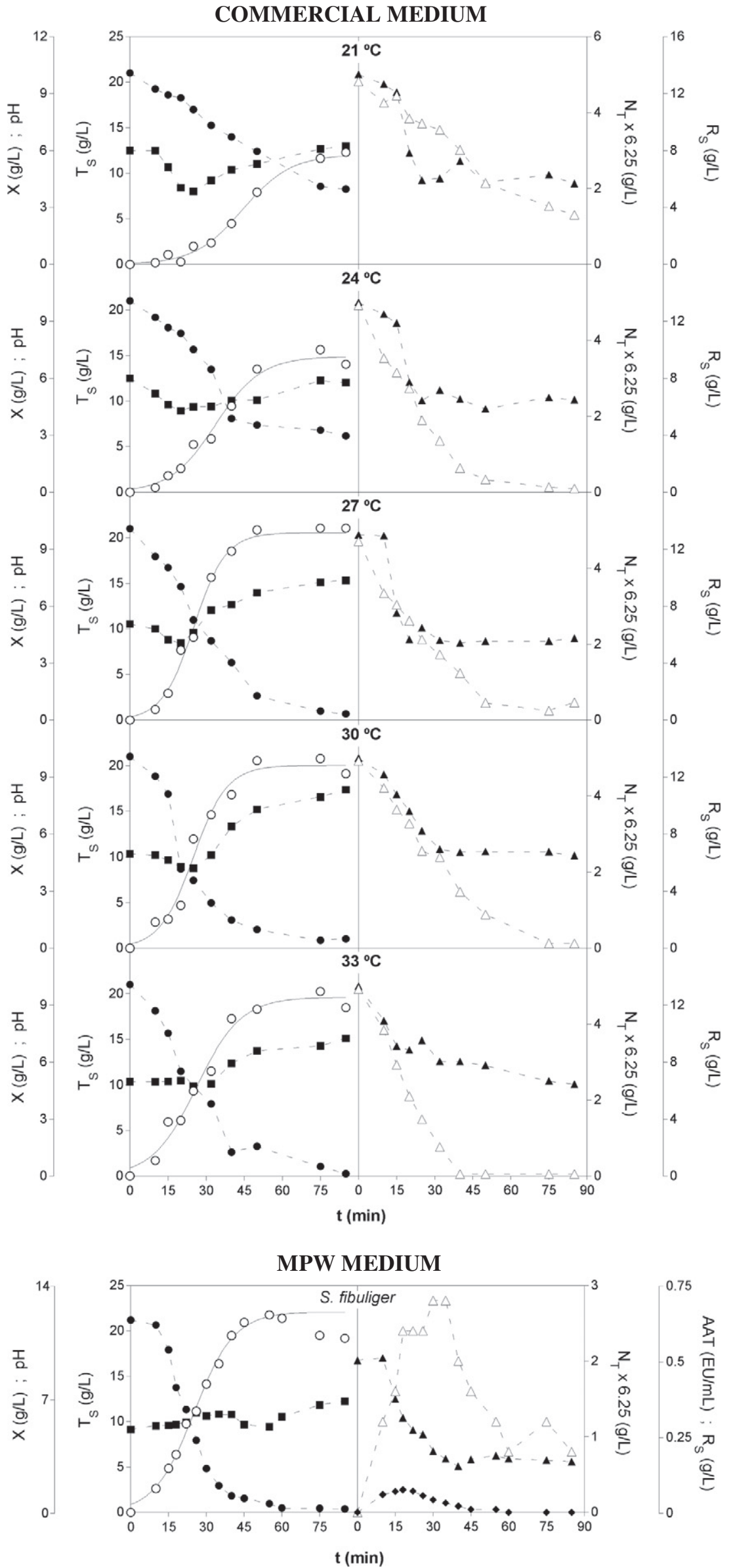
mainly and some $\beta(1 \rightarrow 6)$ links. The common chemical process to separate both is by treating the AI fraction with a weak acid (e.g., acetic acid). Referring to literature regarding the acid extraction, there seems to be a major agreement on those conditions, which are normally applied at low acid concentration and high temperature. The obtained results of the acid extraction of the AI fraction (extracted at the two selected T) are summarized below (Table 3 ) and are as follows: 1) After the acid treatment, independently of the temperature of the alkali treatment, the produced AIAI fraction mainly contains polysaccharides of glucose linked $\beta(1 \rightarrow 3) ; 2)$ AIAS is formed mainly by polysaccharides of glucose with $\beta(1 \rightarrow 6)$ and $\beta(1 \rightarrow 3)$ links; 3$)$ The acid extraction is much less effective when alkali treatment was conducted at $10{ }^{\circ} \mathrm{C}$, compared to treatment at $70{ }^{\circ} \mathrm{C}$; and 4 ) At $70{ }^{\circ} \mathrm{C}$, a purified product is produced with $80 \%$ of $1,3-\beta$-glucans.

These results imply that for extracts of higher purity, the alkali treatment should be carried out at higher temperatures.

\subsubsection{Purification of the AS fraction. Isolation of the glycoprotein fraction}

The separation of proteins from the AS fraction is mainly performed by adding $\mathrm{HCl}$ up to $\mathrm{pH} 4.5$ (protein precipitation at its isoelectric point). In the remaining material, the glycoprotein structures can be isolated using ethanol precipitation (Table 3). In order to optimize the need of ethanol mitigating costs in a potential application at large scale, we have investigated the extraction process (Fig. 5). The variation of pellet dry weight and composition (protein and total sugars) is described by the Weibull equation (Murado and Prieto, 2013b; Weibull and Sweden, 1951) modified to our purposes as follows:

$P(\%)=P_{m}\left\{1-\exp \left[-\ln (1-0.01 n \%)\left(V / \tau_{n \%}\right)^{d}\right]\right\}$

where, $P$ is the components extracted in the ASET fraction (\%), $P_{m}$ is the maximum extracted (\%), $V$ the volume of ethanol, $d$ a shape parameter, $\tau_{n \%}$ the number of volumes needed to obtain a corresponding response equivalent to $\mathrm{n} \%$ of the maximum $\left(\mathrm{n} P_{m} / 100\right)$. In consequence, as presented in Table 4, the most beneficial volume of ethanol would be $\sim 2$ volumes.

\subsection{Antioxidant activity}

Table 5 shows the antioxidant activity obtained for the all fractions and controls. The equivalent AA results by the hydrophilic methods ( $\mathrm{Cr}$, ABTS and DPPH) correlate with each other. The CIT fraction presents the highest $\mathrm{AA}$, with similar values as those obtained by the commercial yeast extract product. An increasing of $T$ in the alkaline extraction leads to a reduction of AA (for AI fraction) and increase of AA (for AS fraction) using in both cases the hydrosoluble methods. These effects are reversed using $\beta C$ reaction (lipophilic one). By combining the results of all the methods applied, the equivalent activity of the final fractions obtained and the controls used, can be stated in the following decrease order: TRP $>$ CIT $>$ YE $>$ CW $>$ AIAS $>$ ASPH $>$ ASET $>$ AIAI $>$ LA $>$ CU.

Other authors have previously reported the antioxidant capacity of pure glucans (Kofuji et al., 2012; Kogan et al., 2008), pure fractions of glucans with different weight and polymerization degree (Tsiapali et al., 2001) and preparations obtained from cell walls of microorganisms (Jaehrig and Rohn, 2007; Jaehrig et al., 2008). In general, our results agree that the AA is weak compared with other bioactive compounds (Barros et al., 2011; Carocho and Ferreira, 2013a,b; Ferreira et al., 2009), but not negligible for industrial applications.
3.5. An approach to the treatment of the mussel wastewater at an industrial scale

The lab scale transformation processes of MPW to products described above were up-scaled to a pre-industrial level using a $70 \mathrm{~L}$ fermenter (BIOSTAT). In all cases, higher yields, compared to those obtained in the lab scale, were found (data not shown). Based on these results, Fig. 6 shows an industrial process for the production of byproducts from MPW. The process is dimensioned according to the size of the hypothetic fermenter $(R=10,000 \mathrm{~L})$. Next, we summarize the possible production yields, commercial applications and the key industrial steps:

1) The wastewater effluents from mussel processing industry $(\sim 4.7 \mathrm{~g} / \mathrm{L}$ of glycogen) are deposited in a sedimentation tank (with a $5 \mathrm{R}$ dimension) which is stabilized at $\mathrm{pH}=4.5$ and allowed to stand for $\sim 12 \mathrm{~h}$ at room temperature for protein deposition. The protein pellet ( $\sim 50 \mathrm{~kg} / \mathrm{R}$ equivalent to $\sim 1 \mathrm{~g} / \mathrm{L}$ of wastewater) is transferred to a drying chamber for removing the water content. The product obtained can be used as protein supplement in feed formulation. In addition, the supernatant is concentrated by ultrafiltration (membrane $100 \mathrm{kDa}$ ) to $\sim 20 \mathrm{~g} / \mathrm{L}$ of glycogen. The resulting concentrate together with the yeast extract (CIT), obtained from the supernatant of a previous similar fermentation, formulates the culture medium. Afterwards, the medium is sterilized by autoclaving prior to the start of the fermentation process with Sf at $27^{\circ} \mathrm{C}, 200 \mathrm{rpm}$ and spontaneous $\mathrm{pH}$ with an initial value of $\sim 5.0$.

2) After $\sim 48 \mathrm{~h}$ of fermentation, cell lysis ( $\sim 140 \mathrm{~kg} / \mathrm{R})$ is performed in an autoclave followed by centrifugation. Then, $1 / 5$ of the supernatant (corresponding to $1 \mathrm{~g} / \mathrm{L}$ yeast extract in the final suspension medi$\mathrm{um}$ ) is recirculated to the fermenter for the formulation of the next culture medium, while the other fraction (4/5) is moved to the drying chamber, obtaining a product $(\sim 40 \mathrm{~kg} / \mathrm{R})$ with nutritive properties (high in minerals and micro-nutrients) and antioxidants, which could be used as a supplement in feed formulation and as partial replacement of commercial antioxidants.

3) The process and product of the, by autoclaving and centrifuging, previously obtained CW pellet, can be classified in two ways: (a) Simple process for the direct preparation of cell walls $(\sim 60 \mathrm{~kg} / \mathrm{R})$ with a product that would be an outlet for feed additive rich in $\beta$-glucan, and (b) More refined and expensive process with a product of pharmacological uses $(\sim 10 \mathrm{~kg} / \mathrm{R})$. The later process includes alkaline ( $\mathrm{KOH}$ or $\mathrm{NaOH} 1 \mathrm{M}$ at $70^{\circ} \mathrm{C}$ ) and acid $\left(1 \mathrm{M} \mathrm{H}_{3} \mathrm{PO}_{4}\right.$ at $70{ }^{\circ} \mathrm{C}$ ) extractions with successive centrifugation steps. The final result is to obtain the AIAI fraction formed by more than $~ 70 \%$ of polysaccharides of $1,3-\beta-$ D-Glucose.

At least three days are necessary to complete these processes as they cannot be executed in continuous mode. Thus, neither would be profitable nor would recycle the wastewater effluents that are dumped into the Galician Rías (estimated 100,000 $\mathrm{m}^{3}$ /year). However, the incorporation of $n$ fermentation and sedimentation tanks would be multiplied by $n$ times to the capability of the process without increasing excessively the initial investment for other industrial equipment such as autoclaves, ultrafiltration plant, centrifuges and extraction tanks, which would need to be properly sized. Considering 100 complete processes annually and a concentration average of $\sim 5 \mathrm{~g} / \mathrm{L}$ glycogen, an industrial plant with $n=20$ would be enough to achieve a full recovery of the wastewaters effluents from the mussel processing industry, generating a range of products that could make the process cost profitable.

\section{Conclusions}

The thermal treatment of the industrial MPW is commonly performed by steam to open the valves and precook or cook the contents. 


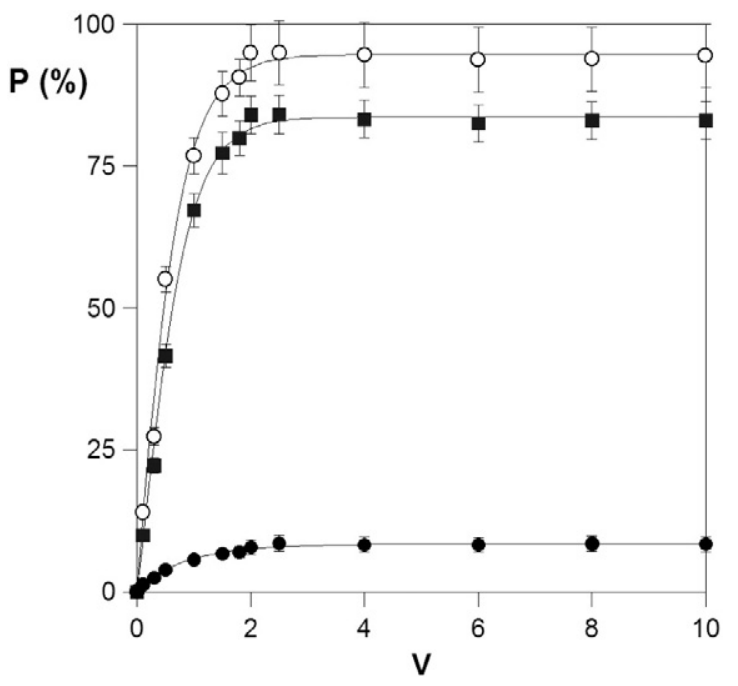

Fig. 5. Dry weight (DW $)$ ) and compositional $\left(T_{N} \times 6.25\right.$ and $\left.T_{S} \boldsymbol{a}\right)$ results obtained from the precipitated material as function of the ethanol volumes used for the AS fraction.

This treatment generates between 300 and $400 \mathrm{~L}$ of MPW/t of mussels. These effluents contribute to the progressive deterioration of the marine ecosystem. To increase the profitability of industrial operations and to satisfy environmental regulations (e.g. reduce the waste emissions as much as possible), low cost and environmentally friendly technologies are applied. Such protocols are based on the transformation of wastewaters into bio-products by microbial fermentation. In all cases, the key aspect is the economic value of the final products derived from residual materials.

MPW can be used as an important ingredient of culture medium for several amylolytic species, obtaining different microbial products. In this work, several species were tested to find the suitable microorganisms for the utilization of MPW growth medium and to maximize the production of SCP. Satisfactory results were obtained with several individual amylolytic yeast and microfungi species. The yields of growth and metabolite production obtained in different fermentation conditions were examined. Overall, the amylolytic yeast $S$. fibuligera was found as the preferred microorganism in the treatment of amylaceous effluents for single cell protein production.

Nevertheless, even if such a microbial treatment by itself reduces the chemical oxygen demand (COD) of the MPW effluents producing a large amount of SCP, there are evidences showing that this production would not be economically attractive to the industrial sector. Therefore, to increase the interest by industry, different fractions of polysaccharides from yeast CW (rich in glucans and mannoproteins) were subsequently isolated by an optimized combination of chemical and enzymatic processes. In addition, the resulting soluble cell fraction (alkali yeast extract) was found as a potential source of antioxidants.

The present work addresses an effort to find a solution to the problem of MPW effluents by means of biotechnological steps with the concomitant production of SCP, antioxidants, $\beta$-glucans and mannoproteins, providing manufacturers as well as local authorities an profitable, eco-

Table 4

Parameter estimations of model (6) for the optimization of the ethanol volumes needed for the ASET extraction. Note that the confidence intervals $( \pm)$ are in percentages.

\begin{tabular}{lllll}
\hline Parameters & & $\mathrm{D}_{\mathrm{W}}$ & $\mathrm{T}_{\mathrm{S}}$ & $\mathrm{T}_{\mathrm{N}} \times 6.25$ \\
\hline$P_{m}$ & $(\%)$ & $94.66 \pm 1.68$ & $83.60 \pm 1.3$ & $8.529 \pm 3.9$ \\
$\tau_{50 \%}$ & (Vol. Et.) & $0.431 \pm 6.97$ & $0.489 \pm 5.3$ & $0.552 \pm 14.4$ \\
$d$ & & $1.101 \pm 8.87$ & $1.196 \pm 7.0$ & $0.903 \pm 15.1$ \\
& $\mathrm{r}^{2}$ & 0.9982 & 0.9989 & 0.9927 \\
$\tau_{97.5 \%}$ & (Vol. Et.) & $1.96 \pm 14.13$ & $1.980 \pm 10.3$ & $3.51 \pm 28.5$ \\
\hline
\end{tabular}

Table 5

Equivalent antioxidant activity of all obtained fractions derived from S. fibuligera in MPW residual medium.

\begin{tabular}{|c|c|c|c|c|c|}
\hline \multirow[t]{3}{*}{ Samples (S) } & & \multicolumn{4}{|c|}{ Antioxidant equivalents } \\
\hline & & \multirow{2}{*}{$\begin{array}{l}\text {-Carotene } \\
\mathrm{mg} \\
\mathrm{BHT} / \mathrm{g} \mathrm{S}\end{array}$} & \multirow{2}{*}{$\begin{array}{l}\frac{\text { Crocin }}{\mathrm{mg}} \\
\mathrm{BHA} / \mathrm{g} \mathrm{S}\end{array}$} & \multirow{2}{*}{$\begin{array}{l}\text { DPPH } \\
\text { mg } \\
\text { Trolox/g S }\end{array}$} & \multirow{2}{*}{$\begin{array}{l}\text { ABTS } \\
\text { mg } \\
\text { Trolox/g S }\end{array}$} \\
\hline & & & & & \\
\hline \multirow[t]{2}{*}{ Bio } & CIT & 39.50 & 56.66 & 1.54 & 2.21 \\
\hline & $\mathrm{CW}$ & 13.61 & 9.42 & 0.19 & 0.13 \\
\hline \multirow{5}{*}{$\begin{array}{l}\text { Alkali extraction of } \\
\text { CW }\left({ }^{\circ} \mathrm{C}\right) \text { AS }\end{array}$} & 10 & 10.69 & 7.23 & 0.16 & 1.39 \\
\hline & 30 & 9.04 & 8.21 & 0.15 & 1.25 \\
\hline & 50 & 5.84 & 11.84 & 0.36 & 2.02 \\
\hline & 70 & 6.40 & 12.65 & 0.56 & 2.20 \\
\hline & 90 & 5.46 & 11.12 & 0.51 & 2.36 \\
\hline \multirow{5}{*}{$\begin{array}{l}\text { Alkali extraction of } \\
\quad \mathrm{CW}\left({ }^{\circ} \mathrm{C}\right) \mathrm{AI}\end{array}$} & 10 & 5.54 & 16.21 & 0.44 & 3.57 \\
\hline & 30 & 6.49 & 15.32 & 0.37 & 3.65 \\
\hline & 50 & 8.85 & 9.25 & 0.23 & 1.77 \\
\hline & 70 & 9.28 & 8.97 & 0.06 & 1.07 \\
\hline & 90 & 4.29 & 7.85 & 0.09 & 1.12 \\
\hline \multirow{4}{*}{$\begin{array}{l}\text { Fractions of } S \text {. fibuligera } \\
\qquad 10^{\circ} \mathrm{C}\end{array}$} & AIAS & 6.17 & 5.85 & 0.54 & 3.34 \\
\hline & AIAI & 1.68 & 3.07 & 0.23 & 1.56 \\
\hline & ASpH & 4.14 & 6.87 & 0.15 & 0.60 \\
\hline & ASET & 2.73 & 1.16 & 0.04 & 1.26 \\
\hline \multirow{4}{*}{$\begin{array}{l}\text { Fractions of } S \text {. fibuligera } \\
70^{\circ} \mathrm{C}\end{array}$} & AIAS & 5.90 & 6.25 & 0.26 & 2.62 \\
\hline & AIAI & 5.67 & 3.16 & 0.07 & 0.92 \\
\hline & $\mathrm{ASpH}$ & 6.35 & 6.99 & 0.41 & 3.19 \\
\hline & ASET & 7.69 & 3.09 & 0.25 & 1.51 \\
\hline \multirow[t]{4}{*}{ Controls } & TRP & 115.71 & 86.12 & 0.87 & 5.09 \\
\hline & YE & 45.29 & 22.20 & 1.01 & 3.64 \\
\hline & $\mathrm{CU}$ & 0.01 & 0.02 & 0.03 & 0.00 \\
\hline & LA & 0.30 & 0.11 & 0.31 & 0.25 \\
\hline
\end{tabular}

designed and environmentally friendly solution that allows to integrate the mussel industry into the ecosystem in a sustainable way.

\section{Acronym list}

\section{Microbial methods}

CMC commercial malt culture.

MPWm Mussel Process Wastewaters medium.

SCP single cell protein.

An Aspergillus niger.

Ao Aspergillus oryzae.

$\mathrm{Rr} \quad$ Rhodotorula rubra.

Sc Saccharomyces cerevisiae.

Sf Saccharomyces fibuligera.

Biomass cell wall fractions

MPW Mussel Process Wastewaters.

CW cell wall

F fractions.

CIT cytoplasm fraction.

AI alkali-insoluble fraction.

AS alkali-soluble fraction.

AIAI alkali-insoluble acid-insoluble fraction.

AIAS alkali-insoluble acid-soluble fraction.

ASET alkali-soluble fraction precipitated with ethanol.

$\mathrm{ASpH}$ alkali-soluble fraction precipitated with an acidic ph.

Antioxidant methods

BHA butylated hydroxyanisole.

BHT butylated hydroxytoluene.

AA antioxidant activity.

ABTS 2,2-azino-bis/3-ethil-benothiazoline-6-sulfonic acid.

$\beta C \quad \beta$-carotene.

$\mathrm{Cr} \quad$ crocin.

DPPH 2,2-diphenylpicrylhydrazyl. 


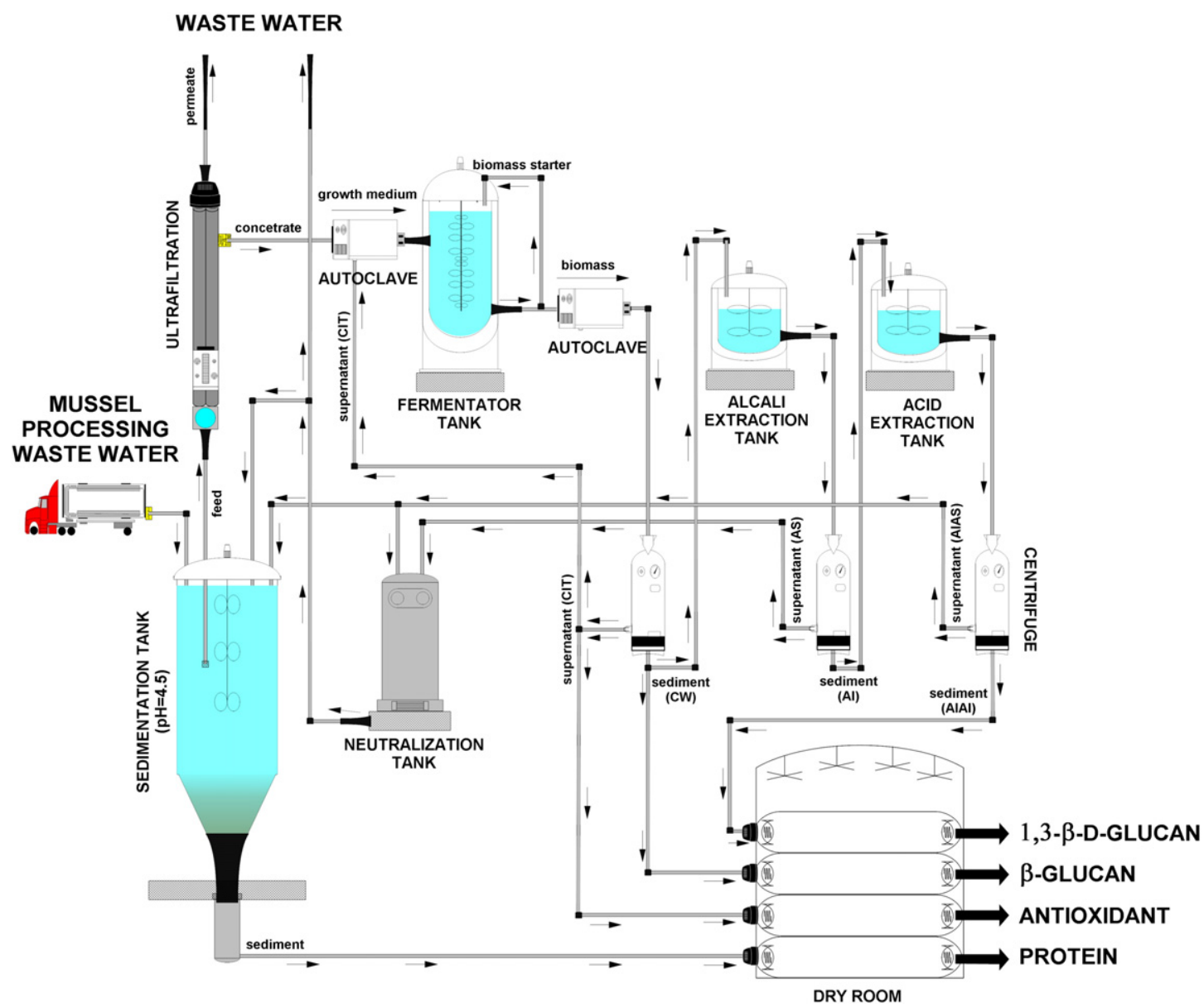

Fig. 6. Schematic diagram for the recovery of mussel wastewaters effluents into products of commercial interest to different industrial sectors.

General analytical techniques

COD chemical oxygen demand.

AAT total amylolytic activity.

$\mathrm{Cz} \quad$ ashes.

DNS dinitrosalicylic acid.

$\mathrm{D}_{\mathrm{W}} \quad$ dry solids.

$\mathrm{F}_{\mathrm{A}} \quad$ fatty acids.

GC Gas chromatography.

$\mathrm{Nt}$ Total nitrogen.

$\mathrm{R}_{\mathrm{S}} \quad$ reducing sugars.

$\mathrm{T}_{\mathrm{H}} \quad$ Total hexosamines.

$\mathrm{T}_{\mathrm{N}} \quad$ Total nitrogen.

$\mathrm{T}_{\mathrm{P}} \quad$ Total proteins.

$\mathrm{T}_{\mathrm{S}} \quad$ Total sugar.

TRP Triptone.

YE Yeast extract.

CU Curdlan.

LA Laminarin.

Parameter analysis

d shape parameter.

$e q v_{A} \quad$ antioxidant equivalents.

$H \quad$ concentration of reducing sugars.

$H_{m} \quad$ maximum proportion of $\beta$-D-1,3 links present in the sample.

$P \quad$ components extracted in the aset fraction (\%).

$P_{m} \quad$ maximum extracted (\%).

$r \quad$ specific rate of hydrolysis $\left(\mathrm{t}^{-1}\right)$.

$t$ time.

$V \quad$ volume of ethanol.

$\mu_{m} \quad$ maximum growth rate $\mathrm{h}^{-1}$. $v_{m} \quad$ maximum growth rate in $\mathrm{gl}^{-1} \mathrm{~h}^{-1}$

$\tau_{n \%} \quad$ number of volumes needed to obtain a corresponding response equivalent to $\mathrm{n} \%$ of the maximum $\left(\mathrm{np}_{\mathrm{m}} / 100\right)$.

$\mathrm{n} P_{m} / 100$ Response equivalent to $\mathrm{n} \%$ of the maximum

$X \quad$ Biomass.

$X_{0} \quad$ Inoculum value of biomass.

$K \quad$ Asymptotic value or maximum biomass production.

$\lambda \quad$ Lag-phase.

$Y_{\mathrm{X} / T_{S}} \quad$ Yields of biomass referred to the consumptions of both $\mathrm{T}_{\mathrm{S}}$.

$Y_{\mathrm{X} / T_{\mathrm{Pr}}} \quad$ Yields of biomass referred to the consumptions of both $\mathrm{T}_{\mathrm{Pr}}$.

\section{Acknowledgment}

The authors wish to thank Xunta de Galicia for the financial support for the post-doctoral researcher M.A. Prieto as part of the "Plan galego de investigación, innovación e crecemento 2011-2015 (Plan I2C)" . We want to express our gratitude to Araceli Menduiña Santomé, Jesus Mirón López, Ana Isabel Durán Durán and Margarita Nogueira Chapela for her professional work in all the analytic determinations and Francisco Javier Fraguas Cadavid for the clarification and centrifugation of mussel effluents and concentration of glycogen by ultrafiltration.

\section{References}

Altan, A., McCarthy, K.L., Maskan, M., 2009. Effect of extrusion process on antioxidant activity, total phenolics and $\beta$-glucan content of extrudates developed from barleyfruit and vegetable by-products. Int. J. Food Sci. Technol. 44, 1263-1271.

Bacon, B.J., Farmer, V.C., Jones, D., Taylor, I.F., 1969. The glucan components of the cell wall of baker's yeast (Saccharomyces cerevisiae) considered in relation to its ultrastructure. Biochem. J. 114, 557-567. 
Bagni, M., Romano, N., Finoia, M., 2005. Short- and long-term effects of a dietary yeast $\beta$-glucan (Macrogard) and alginic acid (Ergosan) preparation on immune response in sea bass (Dicentrarchus labrax). Fish Shellfish Immunol. 4, 311-325.

Barros, L., Carvalho, A.M., Ferreira, I.C.F.R., 2011. Comparing the composition and bioactivity of Crataegus monogyna flowers and fruits used in folk medicine. Phytochem. Anal. $22,181-188$

Bernfeld, P., 1951. Enzymes of starch degradation and synthesis. Adv. Enzymol. 12, 379-427.

Beschin, A., 1998. Identification and cloning of a glucan- and lipopolysaccharide-binding protein from Eisenia foetida earthworm involved in the activation of prophenoloxidase cascade. J. Biol. Chem. 273, 24948-24954.

Bohn, J.A., BeMiller, J.N., 1995. ( $1 \rightarrow 3$ )-B-d-glucans as biological response modifiers: a review of structure-functional activity relationships. Carbohydr. Polym. 28, 3-14.

Buddle, B.M., Pulford, H.D., Ralston, M., 1988. Protective effect of glucan against experimentally induced staphylococcal mastitis in ewes. Vet. Microbiol. 16, 67-76.

Carocho, M., Ferreira, I.C.F.R., 2013a. The role of phenolic compounds in the fight against cancer - a review. Anti Cancer Agents Med. Chem. 13, 1236-1258.

Carocho, M., Ferreira, I.C.F.R., 2013b. A review on antioxidants, prooxidants and related controversy: natural and synthetic compounds, screening and analysis methodologies and future perspectives. Food Chem. Toxicol. 51, 15-25.

Dallies, N., François, J., Paquet, V., 1998. A new method for quantitative determination of polysaccharides in the yeast cell wall. Application to the cell wall defective mutants of Saccharomyces cerevisiae. Yeast 14, 1297-1306.

Dávalos, A., 2004. Extending applicability of the oxygen radical absorbance capacity (ORAC-fluorescein) assay. J. Agric. Food Chem. 52, 48-54.

Diez, L., Guadalupe, Z., Ayestarán, B., Ruiz-Larrea, F., 2010. Effect of yeast mannoproteins and grape polysaccharides on the growth of wine lactic acid and acetic acid bacteria. J. Agric. Food Chem. 58, 7731-7739.

Dubois, M., Gilles, K.A., Hamilton, J.K., Rebers, P.A., Smith, F., 1956. Colorimetric method for determination of sugars and related substances. Anal. Chem. 28, 350-356.

Ferreira, I.C.F.R., Barros, L., Abreu, R.M.V., 2009. Antioxidants in wild mushrooms. Curr. Med. Chem. 16, 1543-1560.

Figueras, A., Santarém, M.M., Novoa, B., 1998. Influence of the sequence of administration of beta-glucans and a Vibrio damsela vaccine on the immune response of turbot (Scophthalmus maximus L.). Vet. Immunol. Immunopathol. 64, 59-68.

Fleet, G.H., Phaff, H.J., 1974. Lysis of yeast cell walls: glucanases from Bacillus circulans WL-12. J. Bacteriol. 119, 207-219.

González, M., Mirón, J., Murado, M., 1987. Culture of Endomyces fibuliger in mussel processing wastes and precipitation with pegs of its extracellular amylolytic system. Biotechnol. Lett. 9, 281-286.

Gonzalez, M.P., Siso, M.I.G., Murado, M., Pastrana, L., Montemayor, M.I., Mirón, J., 1992. Depuration and valuation of mussel-processing wastes. Characterization of amylolytic postincubates from different species grown on an effluent. Bioresour. Technol. 42, 133-140.

Havilah, E.J., Wallis, D.M., Morris, R., Woolnough, J.A., 1977. A micro-colorimetric method for determination of ammonia in Kjeldahl digests with a manual spectrophotometer. Lab. Pract. 26, 545-547.

Hunter, K.W., Gault, R.A., Berner, M.D., 2002. Preparation of microparticulate beta-glucan from Saccharomyces cerevisiae for use in immune potentiation. Lett. Appl. Microbiol. $35,267-271$

Jaehrig, S., Rohn, S., 2007. In vitro potential antioxidant activity of $(1 \rightarrow 3),(1 \rightarrow 6)-\beta-d-$ glucan and protein fractions from Saccharomyces cerevisiae cell walls. J. Agric. Food Chem. 55, 4710-4716.

Jaehrig, S., Rohn, S., Kroh, L., Wildenauer, F., Lisdat, F., Fleischer, L., Kurz, T., 2008. Antioxidative activity of $(1 \rightarrow 3),(1 \rightarrow 6)-\beta$-d-glucan from Saccharomyces cerevisiae grown on different media. LWT Food Sci. Technol. 41, 868-877. http://dx.doi.org/10.1016/j. lwt.2007.06.004.

Janusz, M.J., Austen, K.F., Czop, J.K., 1989. Isolation of a yeast heptaglucoside that inhibits monocyte phagocytosis of zymosan particles. J. Immunol. 142, 959-965.

Kasahara, S., Yamada, H., Mio, T., Shiratori, Y., Miyamoto, C., Yabe, T., Nakajima, T. Ichishima, E., Furuichi, Y., 1994. Cloning of the Saccharomyces cerevisiae gene whose overexpression overcomes the effects of HM-1 killer toxin, which inhibits $\beta$-glucan synthesis. J. Bacteriol. 176, 1488-1499.

Kemmer, G., Keller, S., 2010. Nonlinear least-squares data fitting in Excel spreadsheets. Nat. Protoc. 5, 267-281.

Kim, K., Yun, H., 2006. Production of soluble $\beta$-glucan from the cell wall of Saccharomyces cerevisiae. Enzym. Microb. Technol. 39, 496-500.

Kofuji, K., Aoki, A., Tsubaki, K., Konishi, M., 2012. Antioxidant activity of $\beta$-glucan. ISRN Pharm. 2012. http://dx.doi.org/10.5402/2012/125864.

Kogan, G., Pajtinka, M., Babincova, M., Miadokova, E., Rauko, P., Slamenova, D., Korolenko, T.A., 2008. Yeast cell wall polysaccharides as antioxidants and antimutagens: can they fight cancer? Neoplasma 55, 387-393.

Kulicke, W., Lettau, A., Thielking, H., 1997. Correlation between immunological activity,

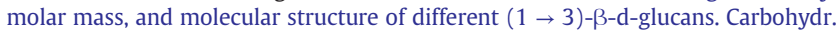
Res. 297, 135-143.

Lowry, O.H., Rosebrough, N.J., Farr, A.L., Randall, R.J., 1951. Protein measurement with the Folin phenol reagent. J. Biol. Chem. 193, 265-275

Manirakiza, P., Covaci, A., Schepens, P., 2001. Comparative study on total lipid determination using Soxhlet, Roese-Gottlieb, Bligh \& Dyer, and modified Bligh \& Dyer extraction methods. J. Food Compos. Anal. 14, 93-100.

Marques, A., Dhont, J., Sorgeloos, P., Bossier, P., 2006. Immunostimulatory nature of Bglucans and baker's yeast in gnotobiotic Artemia challenge tests. Fish Shellfish Immunol. 20, 682-692.
Martínez-Tomé, M., Murcia, M.A., Frega, N., Ruggieri, S., Jiménez, A.M., Roses, F., Parras, P. 2004. Evaluation of antioxidant capacity of cereal brans. J. Agric. Food Chem. 52 4690-4699.

Miranda, M., Siso, M.I.G., González, M.P., Murado, M., Mirón, J., 1987. Amylolysis in systems with $\alpha$-amylase and glucoamylase. A comparative study of six procedures of evaluation. Biotechnol. Tech. 1, 195-200.

Mortensen, A.B., Wallin, H., Appelqvist, L.A., Everitt, G., Gref, C.G., Jacobsen, J., Jensen, K., Jepsen, O.M., Johansen, I.L., Julshamn, K., 1989. Gravimetric determination of ash in foods: NMKL collaborative study. J. Assoc. Off. Anal. Chem. 72, 481-483.

Murado, M.A., Prieto, M.A., 2013a. NOEC and LOEC as merely concessive expedients: Two unambiguous alternatives and some criteria to maximize the efficiency of dose-response experimental designs. Sci. Total Environ. 461-462, 576-586.

Murado, M.A., Prieto, M.A., 2013b. Dose-response Analysis in the joint action of two effectors. A new approach to simulation, identification and modelling of some basic interactions. PLoS One 8, e61391.

Murado, M.A., Gonzalez, M., Pastrana, L., Siso, M.G., Miron, J., Montemayor, M.I., 1993a. Enhancement of the bioproduction potential of an amylaceous effluent. Bioresour. Technol. 44, 155-163.

Murado, M.A., Siso, M.I.G., González, M.P., Montemayor, M.I., Pastrana, L., Pintado, J. 1993b. Characterization of microbial biomasses and amylolytic preparations obtained from mussel processing waste treatment. Bioresour. Technol. 43, 117-125.

Murado, M.A., González, M.P., Torrado, A., Pastrana, L.M., 1997. Amylase production by solid state culture of Aspergillus oryzae on polyurethane foams. Some mechanistic approaches from an empirical model. Process Biochem. 32, 35-42.

Naguib, Y.M., 2000. A fluorometric method for measurement of oxygen radicalscavenging activity of water-soluble antioxidants. Anal. Biochem. 284, 93-98.

Nguyen, T.H., Fleet, G.H., Rogers, P.L., 1998. Composition of the cell walls of several yeast species. Appl. Microbiol. Biotechnol. 50, 206-212.

Omil, F., Méndez, R., Lema, J.M., 1996. Anaerobic treatment of seafood processing waste waters in an industrial anaerobic pilot plant. Water SA 22, 173-181.

Pastrana, L., Gonzalez, M.P., Torrado, A., Murado, M., 1995. A fed-batch culture model for improved production of gibberellic acid from a waste medium. Biotechnol. Lett. 17, 263-268.

Pintado, J., Murado, M., Gonzalez, M., 1993. Joint effect of nitrogen and phosphorus concentrations on citric acid production by different strains of Aspergillus niger grown on an effluent. Biotechnol. Lett. 15, 1157-1162.

Prieto, M.A., Vázquez, J.A., Murado, M.A., 2011. Hydrolysis optimization of mannan, curdlan and cell walls from Endomyces fibuliger grown in mussel processing wastewaters. Process Biochem. 46, 1579-1588.

Prieto, M.A., Vázquez, J.A., Murado, M.A., 2012. Comparison of several mathematical models for describing the joint effect of temperature and ph on glucanex activity Biotechnol. Prog. 28, 372-381.

Prieto, M.A., Murado, M.A., Vázquez, J.A., Curran, T.P., 2013. A new microplate procedure for simultaneous assessment of lipophilic and hydrophilic antioxidants and pro-oxidants, using crocin and $\beta$-carotene bleaching methods in a single combined assay: Tea extracts as a case study. Food Res. Int. 53, 836-846.

Prikler, S., 2009. Advanced Excel for scientific data analysis. In: de Levie, Robert (Ed.), 2nd ed.

Ramasamy, E.V., Abbasi, S.A., 2000. Energy recovery from dairy waste-waters: impacts of biofilm support systems on anaerobic CST reactors. Applied Energy, pp. 91-98.

Rodríguez, I., Chamorro, R., Novoa, B., Figueras, A., 2009. beta-Glucan administration enhances disease resistance and some innate immune responses in zebrafish (Danio rerio). Fish Shellfish Immunol. 27, 369-373.

Rosso, L., Lobry, J.R., Flandrois, J.P., 1993. An unexpected correlation between cardinal temperatures of microbial growth highlighted by a new model. J. Theor. Biol. 162 $447-463$.

Santarem, M., Novoa, B., Figueras, A., 1997. Effects of $\beta$-glucans on the non-specific immune responses of turbot (Scophthalmus maximus L.). Fish Shellfish Immunol. 7, 429-437.

Serpen, A., Capuano, E., Fogliano, V., Gökmen, V., 2007. A new procedure to measure the antioxidant activity of insoluble food components. J. Agric. Food Chem. 55, 7676-7681.

Skjermo, J., Trond, R.S., Hansen, K., Handa, A., Oie, G., 2006. Evaluation of B-(1.3, 1.6)glucans and High-M alginate used as immunostimulatory dietary supplement during first feeding and weaning of Atlantic cod (Gadus mohua L.). Aquaculture 1088-1101.

Slater, M.J., Jeffs, A.G., Carton, A.G., 2009. The use of the waste from green-lipped mussels as a food source for juvenile sea cucumber, Australostichopus mollis. Aquaculture 292, 219-224.

Suphantharika, M., 1997. Determination of optimum conditions for autolyzed yeast extract production. J. Sci. Technol. Dev. 14, 21-28.

Suphantharika, M., Khunrae, P., 2003. Preparation of spent brewer's yeast $\beta$-glucans with a potential application as an immunostimulant for black tiger shrimp, Penaeus monodon. Bioresour. Technol. 88, 55-60.

Tsiapali, E., Whaley, S., Kalbfleisch, J., 2001. Glucans exhibit weak antioxidant activity, but stimulate macrophage free radical activity. Free Radic. Biol. Med. 30, 393-402.

Vázquez, J.A., Rodríguez-Amado, I., Montemayor, M.I., Fraguas, J., González, M.D.P. Murado, M.A., 2013. Chondroitin sulfate, hyaluronic acid and chitin/chitosan production using marine waste sources: characteristics, applications and ecofriendly processes: a review. Mar. Drugs 11, 747-774.

Verhulst, P., 1845. Recherches mathématiques sur la loi d'accroissement de la population. Nouv. Mém. Acad. R. Sci. Belles-Lettres Brux. 18, 1-41.

Weibull, W., Sweden, S., 1951. A statistical distribution function of wide applicability. J. Appl. Mech. 18, 293-297. 